\title{
Cartography of the struggle and resistance of an artisanal fishing community
}

\author{
Cartografia da luta e resistência de uma comunidade de pesca \\ artesanal
}

Antonio Vladimir Félix-Silva', Maylla Maria Souza de Oliveira', Laís Leal da Silva Bezerra'

DOI: $10.1590 / 0103-11042020 E 2211$

\begin{abstract}
The peoples of the sea are threatened by the production of capitalistic colonial subjectivity which, through the state of exception device, has the power to make the ways of living in community in the water territories die. In this cartography, the objective was to analyze processes of subjectivation, struggle and resistance of artisanal fisherwomen and fishermen in a community in the face of wind farms in the Coastal Plain of Piauí, located in the Northeast of Brazil. It is a way of doing research-intervention, in which observant participation was used for data production, arranging reunions, meetings, and public hearings with the research participants, in addition to the use of cartographic journals for the recording of reports and writing of themselves. The discussion and analysis of the results show the sovereignty of capital, impacting the social determination of health by affecting environmental, subjective and social ecologies; struggle and resistance as political dimensions of life and health as a power of life; coexistence of death policies and community life force lines; subjectivation processes that sometimes express subjections, sometimes express singularities when collectively managing the desire to resist policies imposed by the state of exception device.
\end{abstract}

KEYWORDS Fisheries. Racism. Politics. Environmental health.

RESUMO Os povos do mar estão ameaçados pela produção de subjetividade colonial capitalística que, por meio do dispositivo estado de exceção, tem o poder de fazer morrer os modos de viver em comunidade nos territórios das águas. Nesta cartografia, objetivou-se analisar processos de subjetivação, luta e resistência de pescadoras e pescadores artesanais de uma comunidade ante os empreendimentos eólicos na Planície Litorânea do Piauí, situada no Nordeste do Brasil. Trata-se de um modo de fazer pesquisa-intervenção, na qual se utilizou a participação observante para a produção de dados, compondo reuniões, encontros e audiências públicas com os participantes da pesquisa, além do uso de diários cartográficos para registros de relatos e escrita de si. A discussão e a análise dos resultados mostram a soberania do capital impactando a determinação social da saúde ao afetar as ecologias ambiental, subjetiva e social; luta e resistência como dimensões política da vida e de saúde como potência de vida; coexistência de políticas de morte e linhas de força da vida em comunidade; processos de subjetivação que ora expressam assujeitamentos, ora expressam singularizações ao agenciar coletivamente o desejo de resistência às políticas impostas pelo dispositivo estado de exceção.

PALAVRAS-CHAVE Pesqueiros. Racismo. Política. Saúde ambiental. 


\section{Introduction: socio- environmental cartography}

In Brazil, the permanent economic war on traditionally occupied territories is an expression of the genealogy of a production of colonial-capitalistic subjectivity ${ }^{1}$. War on the Amazon, the environment and its ecosystems, war on capital against the existence of traditional communities and minorities that do not commune with the sovereignty of capital and the expansion of contemporary capitalism.

This [...] war is economic, political, legal, military, media [...] although they want to make us believe that everything is under the strictest and most peaceful institutional, social, legal, economic normality2(5).

As we know, the history of colonial economic exploitation began, in the 16th century, with the unbridled commercialization that led to the extinction of approximately 70 million specimens of "ibirapitanga, name given by the coast's Tupi Indians"3(31) to the tree that received the name of brazil wood. Undoubtedly, this story was forged in environmental racism and genocide, subordination and expulsion of natives, trafficking and enslavement of the black people, interdiction of the woman's body, massacres and successive attempts to eliminate the cosmology of religions of indigenous and African origin ${ }^{3-6}$. That is how racism started to be configured as a historical problem, shaping the social determination of health to this day.

From the conception of Robert Bullard, presented by Victor de Jesus, we understand by environmental racism, a dimension of institutional racism that can be defined as:

[...] any policy, practice or directive conducted by governmental, legal, economic, political and military institutions that affects or harms racialIy, in different ways, voluntarily or involuntarily, the environmental conditions of housing, work or leisure of people, groups or communities ${ }^{7(6)}$
The trauma of the foundation of Brazil and the environmental racism with which institutions of violence operate in traditional communities are still far from being overcome, given the death policies mediated by the state of exception device that, since colonization, has operated in the perspective of:

[...] an inclusive exclusion of human life [politically qualified] in the form of naked life [natural life] [...], that is, of a life that was split and separated from its shape ${ }^{8(295)}$.

Thus, trying to subtract it from its political dimension (bios) and reduce it to the purely animal dimension (zoé). Such depoliticization of life forms makes it difficult to deactivate this device that "designates above all a life that can be killed without committing homicide"8(295), although we cannot fail to recognize that one of the effects of this permanent war against the poor, indigenous people, blacks, women and transsexuals ${ }^{2}$, in Brazil, be the death of these subjects and the death of leaders from the countryside, forests and water.

In contemporary time, the peoples of the sea, waters and forests that maintain traces of otherness-solidarity, reciprocity and belonging to their territory of existence ${ }^{9}$ live, forcibly, with the invasion of their territories by enterprises related to agribusiness, with real estate speculation. and their closed condominiums; with the installation of hydroelectric plants, mining companies and wind power stations. As if it were not enough to live with all this, the fishermen and artisanal fishermen face the denial of rights not yet conquered, such as the demarcation of the territory of the waters, in addition to the loss of constitutional rights and the non-implementation of public policies instituted from the 1998 Federal Constitution and the regulation of health equity promotion policies, between 2003 and 2015; today, threatened.

In 2018, Brazil reached 8th place in terms of "installed wind energy generation (U.S. Department of Energy, 2018)"10(25); this is due 
to investment policies, mainly in the states of the Northeast region, in which the territorial extension of parks reaches up to $5 \mathrm{~km}$ from the coast. In the State of Piauí, the developments that are happening stand out, especially in the surroundings of the municipalities of Paulistana and Parnaíba, "favorable regions for the use of wind energy [...], [where there are] the best values of average hourly speed and monthly wind"11(743). In the context of the research that generated this study, the processes of subjectification related to this problem express the correlation of life forces and the policies of death and precariousness of life in a field of disputes between the agency institutions of wind farms and the communities of the Delta do Parnaíba Environmental Protection Area (APA), whose economic activity management plan was only discussed between 2018 and 2019, 22 years after its creation.

APA was created by Decree $n^{\circ} 1.922 / 96$, and covers three states: Piauí, reaching the municipalities of Cajueiro da Praia, Luiz Correia, Parnaíba and Ilha Grande; Maranhão, demarcating the municipalities of Araioses, Água Doce, Tutóia and Paulino Neves; and Ceará, running through the municipalities of Barroquinha and Chaval ${ }^{12}$. In APA, for centuries, extraction has been practiced, including artisanal fishing in its various forms: saltwater, freshwater, and mangrove fishing. The region is abundant in variety of fruits and crustaceans, among them: seafood, shrimp, oysters, lobster and crab. The characteristics of the natural resources of the Coastal Plain region make fishermen and artisanal fishermen develop more than one type of extractivism, which the Brazilian Classification of Occupations (CBO) calls polyvalent fishermen ${ }^{\mathbf{1 3}}$.

\section{The research context}

In this article, we present a cartography of the struggle and resistance of an artisanal fishing community in the Coastal Plain of Piauí in the face of the energy generation projects of the
Omega Wind Power Station (UEO), called Delta 1 (D1), installed in 2014, and Delta 2 (D2), installed in 2016, totaling 62 wind turbines around the beach and in the waters of Pedra do Sal/Parnaíba (PI). The environmental licensing process for the Delta 10 (D10) project (2019/2020), which is ongoing, had a prior license issued by the Secretariat for the Environment and Water Resources of the State of Piauí - Semar (PI), in December 2019. This implies the expansion of the wind farm, with the installation of another 52 wind turbines in areas of the territory that belong to Parnaíba (PI) and Ilha Grande (PI), whose certificates have already been issued by the managers of these municipalities. In disagreement with the Master Plan of each municipality, this will affect even more the food security of the community and access to work and income, given that it will reach areas primarily intended for community tourism, whose project is underway, the raising of animals and of small cattle and the extraction of fruits and other products, according to analysis of the report of the Study of Environmental Impacts (EIA), produced by the consultancy Mineral Engenharia e Meio Ambiente upon request by the UEO"1.

Ilha Grande has a population of 8.734 inhabitants, with 4.556 men and 4.178 women, most of whom are brown and black ${ }^{\mathbf{1 4}}$. The city is surrounded by rivers and dunes, where the headquarters of the Seafood Association of Ilha Grande is located, being better known as Casa das Marisqueiras. Pedra do Sal, a beach located on the coast of the State of Piauí, rural area of the city of Parnaíba, is bathed by a seacoast that is divided into the brave side (a space with more agitated waves) and the tame or inlet side (calm sea, with less waves). The beach, considered a tourist spot, is $15 \mathrm{~km}$ from the city center; and its access is through the PI-116 highway, whose asphalt is unmarked and with stretches totally destroyed. The population is approximately 1.500 inhabitants according to the map of the Basic Health Unit (BHU) of Pedra do Sal15; most do not differ from the population of Parnaíba, which 
corresponds to $65.11 \%$ between browns and blacks ${ }^{14}$. In Pedra do Sal, more than $50 \%$ are directly or by extension part of the artisanal fishing community; not all are against largescale economic ventures, but only a minority are in favor of benefiting in any way or hoping that they can benefit from the expansion of the wind farm.

In the communities affected by wind farms in the two municipalities, there are fisherwomen and artisanal fishermen, shellfish gatherers, crab and manjuba pickers, embroiderers of Pedra do Sal, artisans of Trançados da Ilha, fashion designers who produce costumes and artists who produce fine arts, hammocks and braids made with carnauba straw and handicrafts of other artifacts found and extracted around the territory of the waters. Depending on season, there are women who wake up early to work with cashew extractivism, Urici, Urici-Pitanga, Puçá and Guajiru or other seasonal fruits; there are livestock breeders, such as oxen, goats, chickens, who do it for subsistence and for some sale, in addition to small local merchants who have bars, small inns and small restaurants by the sea. We highlight gangs, dance groups, Boi Estrela do Mar, Boi da Ilha; the coconut master, singer, poet and fisherman, Mr. Garajau; the Seafood Festival; the Bom Jesus dos Navegantes Festival, the São Pedro Festival, the Regatta and the festivals and offerings to Iemanjá that are held annually, on February 2nd and August 15th.

The history of these communities, traditionally occupied by fisherwomen and artisanal fishermen, is part of the history of the peoples of the sea and spans several generations. Mr. Pescada (70 years old) calculates from his great-grandfather and his ancestors, saying that his family has been in this territory for more than 250 years. The main source of income and sustainability is family-based economic production, through the extraction of artisanal fishing and other products. According to the National Comprehensive Health Care Policy for Rural,
Forest and Water Populations, fishermen and artisanal fishermen are extractivists, that is,

[...] people and communities, with their cultural specificities, whose production of wealth for their development is based on the collection of products from natural sources, such as forests, young forests (capoeiras), rivers, streams, lakes, wetlands, mangroves, flood forests, ocean beaches, and the high seas, among others ${ }^{16(21)}$.

This way of life is threatened by wind farms in several aspects, both in terms of territorialization and limitation of the field for carrying out artisanal fishing and other extractive activities, violating the right to come and go from the community by limiting the forms of access, as for cutting cashew trees, grounding ponds, contamination of the water table; alteration of the fish flow between fresh and salt water, change in the cycle of migratory birds and death of others. The imbalance caused by the generation of the so-called 'clean energy' affects the ecologies: environmental, subjective and social17, that is, it affects health and its social determination, as we will show from the community's narratives, with the crossings and the transversalities that mark the analysis of the mapped subjectivation processes.

Faced with this problem-situation, how are the processes of subjection, struggle and resistance constituted by wind farms in existential territories traditionally occupied by fishermen and artisanal fishermen? To think about this problematization, we present an excerpt from an intervention research (CAAE 03051018.8.0000.5214) on subjectivation processes, social movements and social determination of the fishermen and artisanal fishermen of the Coast Plain who live in the waters that make up the Delta of Parnaíba APA.

In this article, we present only the production of knowledge generated by the objectives: a) Map processes of struggle and resistance of fisherwomen and artisanal fishermen in the face of the economic undertakings of a wind farm; b) Map impacts generated by the 
implantation, installation and operation of D1 and D2 in the ways of life of fisherwomen and artisanal fishermen and in the territory traditionally occupied by the fishing community; and c) Characterize the struggle of the communities of Pedra do Sal and Ilha Grande to stop the D10 enterprise, from the questioning of the modes of subjection and the recognition of the ways of life that resist the policies of death to the waters.

\section{Cartography as a way of doing research-intervention}

In this context of disputes, the interventions are produced by the community, so that the researcher and the researchers compose the cartographies of the struggle drawn by the resistance movement. This cartography is configured as a way of doing research-intervention and as a method of qualitative research in psychology, allowing the data production strategy, called participant observation, to be detached for observant participation ${ }^{18}$. For the production of information, we used the cartography of narratives, orality and self-writing, in the Foucauldian perspective of saying true ${ }^{\mathbf{9}, 20}$ with records in cartographic diaries, from the composition of several psychosocial landscapes, between 2018 and 2019. Therefore, we had as methodological strategy the observant participation in the following moments: a) A Tent for Arts and Health Education and seven Fisherman Conversations to hear narratives and tales by the beach, in Pesqueira, a house located in Pedra do Sal, which serves as a support for storing fishing artifacts, a place of passage for those who goes and returns from the sea; b) Fisherman, Fisheries and Aquaculture Week, in Luís Correia (PI); c) I Seminar on Traditional Peoples in the Northern Region of Piauí at the Federal University of Piauí (UFPI); and d) Four meetings organized by ICMbio to elaborate the APA Delta management plan; e) Two collective meetings, organized by the wind farm; f) three meetings with the community, held before the hearings, in Ilha Grande and Pedra do Sal; and g) Two public hearings coordinated by Semar, held on August 14, 2019, in Ilha Grande, and August 15, 2019, in Pedra do Sal - in addition to participating in meetings, meetings, forums and protests, when confronting the developments related to the construction of resorts, kitesurfing events and public hearings related to the presentation of the EIA and the license for installation of D1 and D2.

\section{Discussion, results and cartographic analysis of subjectivation processes}

In a conversation circle for storytelling and community narratives, carried out by UFPI teachers(s), Mr. Zé Boreta (currently, 60 years old) narrates:

[...] We are prevented from carrying out our plant extraction by pruning our freedom to come and go in our lands. People, who have lived here for a long time, still do not have possession of our land. But, some foreigners who arrive already claim to be owners. This is an abandonment of the government with the population. It is funny, but it is real, because we are the ones who choose the weapons to kill us by choosing our political representatives who leave us in the lurch. And now, what will become of our Pedra do Sal: Only the future will tell us. What we can do to prevent this mass destruction, we will do, we will fight21(33).

The decrees, laws and environmental licenses make up the political-legal order for the exploitation of this great economic enterprise, they constitute the death policies or weapons denounced by Mr. Zé Boreta. There is a paradox related to access to the territory of the waters, considering that a proposal for the urbanization of Pedra do Sal is underway; at the same time, a land tenure regularization 
process is underway, whose request was initiated in 2014 and resumed in 2016 by another management of the Community Association. The lack of a community Rural Environmental Registry (CAR) generates conflicts between 'owners' of leased-lands and the community. However, in some communities in the municipalities of Maranhão, the UEO and governments are encouraging the CAR, so that community associations can lease the area for installation and operation of wind farms. Such agency exposes the community to processes of subjectivity and subjection that define 'precisely biopower'22, the power over life.

In her thesis, Eugênia Figueiredo ${ }^{\mathbf{2 3}}$ shows how, in 2005 , the community - with the support of the institutions of justice and environmental law, the Public Prosecuto's Office, ICMbio, Ibama and UFPI teachers(s) - acted: it filed for an injunction and managed to block the environmental license for the construction of a complex tourist resort in Pedra do Sal, which intended to relocate the community to another area and build a closed condominium with a helipad, sports courts and a golf course. In 2015, entrepreneurs returned; this time, the construction would be in an area of the beach that belongs to the Union and would affect fishing, mangroves, dunes and lagoons. Figueiredo says that the strength of capital was so strong that the voice of the community was not heard, even though it was manifested in "public hearings, in acts of protest and in meetings with businessmen and the supervisory body (ICMbio, SEMAR)"23(107).

In the Tent for Arts and Health Education (TeArES) that we organized, Mr. Buchudo (55 years old), when referring to the Pedra do Sal community, states:

here was a common land, with the right and freedom to come and go, before the arrival of wind farm [...] Here, now, is to live or die! Health is precarious!

In the city of Paranaíba-PI, only $23.5 \%$ of households have adequate sanitation, and in the city of Ilha Grande-PI, there are only $4.4 \%$ of households with adequate sanitation ${ }^{\mathbf{1 4}}$. In communities where fisherwomen and artisanal fishermen live, there is no garbage collection in all places and, in addition to the lack of basic sanitation, there is often no drinking water. There are areas discovered in the territory due to the lack of Community Health Workers (CHW); and, at Pedra do Sal, there were no home visits by the Family Health Strategy (FHS) teams before the extinction of the Family Health Support Center (Nasf).

Unlike the absolutist monarchs who exercised the power to make people die and let live until the 16th, 17th and 18th centuries ${ }^{24}$, as a way of supporting themselves and keeping subjects in ignorance and total obedience, in contemporary society, the necropolitics is one of the ways to defend the modernization process made possible by colonization and globalization and sustained by the expansion of the precariousness of life. In the context of globalization of the economy, financialization of enterprises and concentration of profit, the so-called nation-states are less and less concerned with making life and the lives of some populations of classes and social groups considered vulnerable, controlling birth rates and longevity, and they are increasingly concerned with "how to save the economy, the life of capital"25(9).

From slavery to the globalization of the economy, capital has been imposing itself on what remains of the nation-state and has been organizing death policies that mark contemporary capitalism in different contexts. In this sense, slavery is considered by Mbembe as "one of the first manifestations of biopolitical experimentation"26(27), being the state of exception, according to Agamben ${ }^{\mathbf{8}, 22,27}$, the agency of the political dimension of life (bios) and naked life (zoé); such a device serves to regulate, through the legal-political order, the sovereignty of capital. In the context of the research, this is evident with the incentive to companies, the tax exemption and prior licenses for large-scale economic enterprises, 
in addition to decrees and bills that guarantee that the APA can be exploited for the expansion of commercial tourism.

"[...] The territory is life. Water is life [...]. Capital is death. Death to the waters. Death to the lives of humans and non-humans [...]". Even with some variations, these are stated in the thesis of Mrs. Celeste ( 65 years old), artisanal fisherwoman and one of the coordinators of the Fishermen and Fisherwomen Movement (MPP). That's how she starts and ends her participation in the conversation circles. In addition to the place of speech and representativeness ${ }^{\mathbf{2 8}}$ referring to the MPP that covers 18 states in Brazil, its report and the writing of itself19,20 are expressions of subjectivation processes that configure life power, expression of community health as the ability to update the forces of through political struggle and active resistance.

We find convergence between what the statements of Mrs. Celeste denounce and the concept of production of colonialcapitalistic subjectivity ${ }^{1}$, in the contexts of contemporary society, in which we are dying, but in which we insist on living, coexisting and resisting as minorities: peripheral, practitioners of candomblé, practitioners of umbanda e users of ayahuasca, indigenous, black women, lesbians, gays, transvestites, transsexuals, intersex etc. Mrs. Celeste's thesis, defended collectively by social movements, traditional peoples and communities, translates this conception of subjectivity, essentially manufactured by the institutions of the control society, sometimes supported by the servile desire to produce a colonial-capitalistic unconscious ${ }^{\mathbf{1 , 2 9}}$, now problematized by the collective agency of the desire for communism, a desire for the world that becomes a common minority becoming ${ }^{30,31}$. In the traditional community of fisherwomen and artisanal fishermen, what sustains the political struggle for life is the resistance against the necropolitical norm of the state of exception that characterizes contemporary capitalism "that intends to dictate all forms of affiliation"32(4) pulling all of us into the knits of this colonial-capitalistic subjectivity production.

The weaving of the embroiderers of Pedra do Sal and the Braided Island express elements of the waters' territory, so that the lines of fishing, the art of embroidery and the artifacts of fishing are mixed with the lines and forces of life. Thus, we recognize processes of semiotization in art, in the struggle and resistance of the community that coexist with processes of subjectification and desubjectivation. While fishing or gathering fruit, they talk about life; some families 'sing': "we live off fishing, come all of you help, fishing throughout the sea, Bom Jesus dos Navegantes!". In this way, the community presents itself, seeking to resist the effects produced by large enterprises and producing mental health in itinerant living spaces.

The culture of these peoples of the sea, with Bom Jesus dos Navegantes, Iemanjá and other symbols of religiosity and their connection with the territory of the waters, resists as an expression of the right to life and against the forces of capital. Nevertheless, culture does not always occupy a place of resistance. There are moments in which culture is consumed and used by the UEO's own enterprises, such as in the production of videos on artistic expressions of the community, shows and exhibitions of the community's handicrafts in the shopping center, generating only a consumer culture, as well as in the rehearsal of creation of a fisheries museum, in addition to the exhibition of archaeological material, found during excavations for the installation of the wind farm. This exhibition was held at Casa Simplício Dias, already anticipating the forgetfulness of the memory of the waters.

At the end [of this production of subjectivities], there is only one culture: capitalism. It is a culture that is always ethnocentric and intellectocentric (or logocentric), because it separates semiotic universes from subjective productions $29(31)$. 
We found convergence between the studies and the results of other studies carried out ${ }^{\mathbf{1 0}, 23,33,34}$. The problems pointed out by the communities are common, including with regard to damage to health; they differ in the number of the population affected and whether the devastation and destruction affect fauna and flora with mobile or fixed dunes with vegetation, in addition to the difference relative to the singularities of the territories in each inhabited area.

In this study, we are talking about the struggle for life, the social determination of health and the resistance to death to common life in the territory of waters with sensitive ecosystems in the only Delta of the Americas and the third largest in the world, an APA, in which we also find an Extractive Reserve (Resex). The Parnaíba Delta is formed by an archipelago with an area of $2.700 \mathrm{~km}^{2}$, composed of 72 islands, thus covering Piauí, Maranhão and Ceará, configuring a socio-environmental map with a rich water table and an immense biodiversity with sensitive ecosystems.

In Xavier/Camocim-CE, a village with 20 families and 66 inhabitants who live from artisanal fishing, extraction and family farming, Mendes reports that "the waterproofing and compacting of soils for the construction of access roads, construction sites and areas for the storage of materials"33(161) affected the community in such a way that the road was the only thing considered by the population as positive. Unlike Xavier, in Pedra do Sal, neither the road, external to the UEO facility, is considered good for good living. The social subjection imposed on the community's way of life generates socioenvironmental impacts and affects health: after the construction of the cobblestone road, which in the winter turns to mud and in the summer there is dust, problems arose that were reported in public hearings and in collective meetings proposed and carried out by the entrepreneur, with the participation of the community and representatives of the institutions that support the community.

At the collective meeting, held at Pedra do Sal, Professor Maria (40 years old) starts by asking what the areas of reforestation are, already made by the UEO, to compensate for the negative environmental impacts of D1 and D2 projects. She contests the following:

What we see is that nothing has been done. So, how does this communication take place with you? Because you pass by here in your cars with windows closed. Try to pass by here with the windows open, with dust and mud affecting, including the children of the day care center, who started to have respiratory diseases.

Mr. Raimundo Boreta (62 years old) problematizes: "the road was made so that you from Omega have access, it was not for improving the community".

During the reading of the questions sent to the table, in the public hearing of Pedra do Sal, the secretary of the environment, when reading questions sent by the plenary, announces: "do you think you are deceiving me? do you think that a teacher doesn't recognize the same letter?". The racism that emerges from these statements is immediately analyzed by a large part of the plenary that screams almost in unison: “Teacher!”. Celiane (23 years old), from MPP, disputes:

[...] How do you call yourself an environmental ethics teacher and don't know that here, in the community, there are fishermen who don't know how to read and write?

At the hearing held the previous day, the tourism secretary defends the expansion of the wind farm:

Ilha Grande is collaborating with the generation of clean energy and the creation of 600 temporary jobs. Ilha Grande is proud of that. But they accuse the company of causing anguish and anxiety in the community. [...]. There are small breeders who have a life's work with few head of cattle and who will 
be impacted, but after talking with the company, she promised not to affect it so much.

The analysis of these subjectivation processes expresses a paradox of subjection and servitude, given the social function of these representatives of the state public power, the 'community's representative' and the municipal public power; this social subjection coexists with the expression of a servile desire to capital.

The social management of the UEO tries to organize male and female residents of the community, presidents of community associations, managers and secretaries of the municipalities to join the D10 installation campaign, making more than 50 home visits to talk about the project to expand the wind farm, social programs and mitigation of environmental impacts. This agency comes to produce discomfort in the community. Irineudo ( 54 years old), current president of the Pedra do Sal Community Association, during one of the three meetings prior to the public hearings that we mapped, shares:

[...] they [from the wind farm] are pitting people in the community against each other, going from house to house. Visiting me all the time. This is sad!

The community finds itself thrown into the experience of a concomitantly strange and familiar state, which destabilizes its contour and the images it has of itself and of the world, causing malaise $\mathrm{e}^{\mathbf{1 ( 5 6 )} \text {. }}$

In the public hearing, Andreia, a psychologist and representative of the Municipal Health Council of Ilha Grande, made the following problematization: "studies in relation to bats show that, in short, their death has been due to hemorrhage and not due to impact on the turbines [wind turbines]". Concerned, she adds, "we are also mammals". And reports:

Noise emission in type $B$ and $C$ decibels that are called infrasound are felt as vibration in the body and can cause: sleep disturbances; headache; ringing in the ears; pressure in the ear; nausea; dizziness; tachycardia; irritability; concentration and memory problems; panic episodes with a feeling of internal or tremulous pulsation when waking or sleeping.

There is a contradiction between the care that emerges as a device of the subjectivation processes that mark the statements of the municipal health counselor and the State institutions that endorse the UEO enterprise. For most people in the community who attended the hearings, the UEO does not produce life in the territory, its social programs serve only to denounce the absence of public policies and the incompetence of governments and to confuse the local population. In addition to the energy it produces does not serve the community, as it is a producing company, and not a distributor, in these five years of occupation of the territory by the UEO, the monitoring programs in the areas of D1 and D2 operate in the logic of monitoring and repress, injuring the right to come and go from the community, affecting the social determination of health with regard to access to water territory and food security.

In relation to the surveillance and control of the bodies, in restricting the freedom to come and go of the community, subjection and segmentation of the modes of subjectivation prevail. Mr. Zé Boreta, who at the collective meeting had questioned:

Do these wind turbines built with cement and other products, releasing oils; don't they pollute the water? You who have studied and have schooling, say it.

In the public hearing, he responds, translating for those who still don't understand what is happening:

[...] Another 52 wind turbines will be installed. It is eviler for us. It is more oil pollution in the lagoons. It is eviler for each of us. We are meeting in a cornered gear, with no way out. They are surrounding 
us, they are surrounding us on all sides. They are curtailing our right to come and go. Before, we had the right. Today, we no longer have it because there is a guard who says: 'here, you cannot pass'. Why if we live here? Why did they take away our right? You don't know that because you have never lived with that reality. I'm talking about us fishermen. We who reside in the community. I'm talking about us fishermen, not those who have a good salary, which I am not against. [...]. But you cannot say that you are not ending the island that you are not ending the environment. I'm saying, because I know. There will be more pollution. There will be more destruction. And more challenge for us.

It is the challenge of facing environmental racism. It is the challenge of fighting to deactivate the disposition of the state of exception and facing a set of policies of death to the territory of the waters, death to the political dimension of life in that territory through the agency of the ways of life for culture and production consumption desire ${ }^{29}$. In this sense, the mortification of the existential territory is a machination for the disorderly and unrestrained appropriation of lands, waters and winds, an effect and effect of power relations whose social, legal, economic and political actions corroborate the exorbitant profit of wind farms in name of sustainable economic development, even if such an undertaking affects the social determination of the health of the artisanal fishing community, with regard to food security, access to income and the territory itself.

\section{Cartography of cartographies: final considerations}

The production of colonial-capitalistic subjectivity ${ }^{1}$ tries to maintain a policy of death to the territory of the waters - in the APA Delta - and to other traditional communities in Brazil. The state of exception has life policies for those who deserve to live with the benefits of contemporary capitalism and policies for dying the ways of life of those who live in traditionally occupied territories. In the territory of waters, large-scale economic ventures generate conflicts and frustration in the community, given that hegemonic activities involve companies with high purchasing power and occur overlapping until decisions to the contrary in public hearings, in forums and in meetings about regulation economic activities in APA.

As we saw earlier, the policy of death to existential territory begins with the production of conflicts and social vulnerability, affecting food security and the production of the familybased economy, access to the territory and artisanal work, sources of income generation for the population. extractive community. These devices emerged from the analysis of subjectivation processes whose problematization made us see and makes us think how the social determination of health is affected, shaking and compromising the bases of psychosocial health promotion processes ${ }^{35}$.

Given the complexity of these subjectivation processes that are configured in the struggle for the political dimension of life and in the resistance against the sovereignty of capital imposed in APA Delta Parnaíba, we recognize that there is an articulation of economic, legal, educational, political, social and environmental devices for the implementation of wind farms in the waters. This articulation is part of the capitalist agencies that capture socio-environmental resources from sensitive ecosystems and that try to co-opt communities made up of fishermen and artisanal fishermen, extractivists, artisans and small traders, such as owners of small inns, bars and small restaurants.

One of the devices of these agencies is environmental racism that is triggered by the sovereignty of capital to compose the state of exception, with the federal, state and municipal governments, politicians and leaders of some institutions.

There are health problems related to environmental determinants that worsen in 
periods of rain, due to the lack of garbage collection in all locations; in addition to lack of basic sanitation, drinking water is often lacking; access to health services is hampered by the lack of CHW coverage and public transportation. As if these environmental and sanitary health problems were not enough, the precariousness of life expands with the imposition of the sovereignty of capital, affecting the social determination of health and the political dimension of life in such a way that the imbalance caused by the generation of the so-called 'clean energy' affects environmental, subjective and social ecologies with regard to food security, access to artisanal fishing, income, water territory and environmental health in the territory.

In this field of disputes, the struggle in defense of environmental health and resistance to the sovereignty of capital as ways of sustaining a way of life are configured as health producers. In the same way, community health gains strength as a power of life and collective agency of the desire of fisherwomen and artisanal fishermen, as we demonstrate through the analysis of subjectivation processes that conform to the reports and writing of themselves ${ }^{19,20}$ presented. The precariousness of life and the social determination of health, therefore, does not prevent them from living in "an area of community life"22(13) and from being able to lead a way of life in the traditional artisanal fishing community, in which "life itself is at stake, and in its living, is at stake above all its way of living"27(13-14) and producing health.

\section{Collaborators}

Félix-Silva AV (0000-0003-3084-379X)*, Oliveira MMS (0000-0001-6818-8319)*, Bezerra LLS (0000-0003-0650-0498)* also contributed to the elaboration of the manuscript.

\section{References}

1. Rolnik S. Esferas da Insurreição. São Paulo: n-1 edições; 2018.

2. Pelbart PP. Estamos em guerra. São Paulo: n-1 edições; 2017.

3. Schwarcz LM, Starling HM. Brasil: Uma biografia. São Paulo: Companhia das Letras; 2015.
4. Castro EV. Os Involuntários da Pátria. São Paulo: n-1 edições; 2016.

5. Castro EV. Brasil, o País do Futuro do Pretérito. São Paulo: n-1 edições; 2019.

6. Nascimento A. O Genocídio do negro brasileiro: Processo de um Racismo Mascarado. São Paulo: Perspectiva; 2016.
*Orcid (Open Researcher and Contributor ID). 
7. Jesus V. Racializando o olhar (sociológico) sobre a saúde ambiental em saneamento da população negra: um contínuo colonial chamado racismo ambiental. Saúde soc. [internet]. 2020 [acesso em 2020 maio 25]; 29(2):e180519. Disponível em: https://doi.org/10.1590/ s0104-12902020180519.

8. Agamben G. O uso dos corpos. São Paulo: Boitempo; 2017. Série [Estado de sítio, Homo Sacer, IV, 2].

9. Santos BS. Direitos humanos, Democracia e Desenvolvimento. In: Santos BS, Chauí M. Direitos humanos, Democracia e Desenvolvimento. São Paulo: Cortez; 2013. p. 41-133.

10. Brannstrom AGC. Diretrizes para o Planejamento Socialmente justo com vistas à Implantação de Parques Eólicos no Brasil. In: Gorayeb A, Brannstrom C, Meireles AJ, organizadores. Impactos socioambientais da implantação dos parques de energia eólica no Brasil. Fortaleza: Edições UFC; 2019. p. 25-44.

11. Estudo de Impacto Ambiental. OMEGA Energia Complexo Eólico Delta 10. Piauí: Mineral Engenharia e Meio Ambiente; 2018.

12. Brasil. Decreto de 28 de agosto de 1996. Casa Civil. Dispõe sobre a criação da Área de Proteção Ambiental Delta do Parnaíba, nos Estados do Piauí, Maranhão, e Ceará, e dá outras providências, 1996 [internet]. [acesso em 2019 maio 20]. Disponível em: http:// www.planalto.gov.br/ccivil_03/DNN/Anterior\%20 a\%202000/1996/Dnn4368.htm.

13. Cadastro Brasileiro de Ocupações. Pescador Polivalente [internet]. 2017 [acesso em 2019 maio 20]. Disponível em: http://www.mtecbo.gov.br/cbosite/pages/home.jsf.

14. Instituto Brasileiro de Geografia e Estatística. Censo Demográfico - 2010 [internet]. 2011 [acesso em 2019 maio 20]. Disponível em https://censo2010.ibge.gov. br/.

15. Parnaíba. Prefeitura. Mapa da Unidade Básica de Saúde da Pedra do Sal. Parnaíba: UBS Pedra do Sal, 2018.
16. Brasil. Ministério da Saúde. Política Nacional de Saúde Integral das Populações do Campo e da Floresta. Brasília, DF: Ministério da Saúde; 2013.

17. Guattari F. As três Ecologias. 13. ed. Campinas: Papirus; 2002.

18. Barros LP, Kastrup V. Cartografar é acompanhar processos. In: Passos E, Kastrup V, Escóssia L, organizadores. Pistas do método da cartografia: pesquisa-intervenção e produção de subjetividade. Porto Alegre: Sulina; 2009. p. 52-75.

19. Rago LM. A aventura de contar-se: feminismos, escrita de si e invenções da subjetividade. São Paulo: UNICAMP; 2013.

20. Butler J. Relatar a si mesmo. Belo Horizonte: Autêntica; 2015.

21. Rocha FMR, Braga OR, Melo SP. A Sereia Mariá e as Histórias das Comunidades da APA Delta do Parnaíba. Parnaíba: Sieart; 2015.

22. Agamben G. Uma biopolítica menor. São Paulo: n-1 edições; 2016.

23. Figueiredo EBG. É doce morrer no mar? Análise psicossocial do ingenium da pesca artesanal. [tese]. São Paulo: Pontifícia Universidade Católica; 2018. 175 p.

24. Hui Y. Da consciência infeliz dos neorreacionários. São Paulo: n-1 edições; 2019.

25. Lazzarato M. É o capitalismo, estupido! [internet]. 2020 [acesso em 2020 maio 25]. Disponível em: https://n-ledicoes.org/016.

26. Mbembe A. Necropolítica: biopoder, soberania, estado de exceção, política de morte. 2. ed. São Paulo: n-1 edições; 2018.

27. Agamben G. Meios sem fim: notas sobre a política. Belo Horizonte: Autêntica; 2017.

28. Ribeiro D. Lugar de Fala. São Paulo: Letramento; 2019. 
29. Guattari F, Rolnik S. Micropolítica: Cartografia do desejo. 10. ed. Petrópolis: Vozes; 2010.

30. Guattari F. Revolução Molecular: pulsações políticas do desejo. 3. ed. São Paulo: Brasiliense; 1981.

31. Negri T, Guattari F. As verdades Nômades: por novos espaços de liberdade. São Paulo: Autonomia Literária; 2017.

32. Mbembe A. Necropolítica. São Paulo: n-1 edições; 2018.

33. Gondim LB, Oliveira CD, Xavier TF. Os ventos da Ibiapaba: Percepções sobre o litígio territorial Ceará - Piauí no impacto dos parques eólicos. In: Gorayeb A, Brannstrom C, Meireles AJ, organizadores. Impactos socioambientais da implantação dos par- ques de energia eólica no Brasil. Fortaleza: Edições

UFC; 2019. p. 213-228.

34. Mendes JS. Contradições do discurso sustentável da energia "limpa": Problemas locais versus soluções regionais. In: Gorayeb A, Brannstrom C, Meireles AJ, organizadores. Impactos socioambientais da implantação dos parques de energia eólica no Brasil. Fortaleza: Edições UFC; 2019. p. 159-178.

35. Brasil. Ministério da Saúde. Política Nacional de Promoção da Saúde. 3. ed. Brasília, DF: Ministério da Saúde; 2010.

Received on 09/30/2019

Approved on 07/03/2020

Conflict of interests: non-existent

Financial support: non-existent 